\title{
Religiositas Matematika dalam Sekte Pythagorean
}

\author{
Wiwit Kurniawan \\ Nusantara Research Institute (NRI) Jogjakarta \\ wiwitkurniawan1987@gmail.com
}

\begin{abstract}
Presently, mathematic is commonly known as scholarly studies specialized on worldly matters, step aside from mysticism. However, such perspective does not prevail on Pythagorean traditional sect. For this sect, mathematics constitutes divine activities and comprises of metaphysical elements. Pythagorean is a group of derived from Pythagoras disciples. Besides studying of mathematic, they also have tight tradition and mystical belief. This paper aims to analyze the religious side of Pythagorean sect which relates to mathematics. Many concept of mathematics in some universities recently come from Pythagoras thoughts. One of Pythagoras ideas used till now is Pythagoras's theoretical framework of the comparative quadrate of trilateral sides, $\left(a^{2}+b^{2}=c^{2}\right)$. This mathematic concept is widely used, taught and taken as irrelevance with mystical matters, metaphysical and religiosity. The religious elements that have been analyzed refer to Durkheim's concept of religion on belief in a sacred, namely totem, taboo and ritual. This study argues that Pythagorean conviction of mathematics, related to number, geometry and ratio are categorized as a kind of religious form. Pythagorean sect possessed belief to the sacred, totem, taboo and ritual which is connected with their conception on mathematics.
\end{abstract}

Keywords: Pythagorean, Religiosity, Numbers, Math. 


\section{Pendahuluan}

Saat ini matematika dianggap sebagai suatu keilmuan yang bersifat duniawi dan jauh dari mistik, namun dalam tradisi sekte Pythagorean matematika adalah aktivitas keilahian dan mengandung unsur metafisik. Pythagorean adalah sebuah komunitas dari murid-murid Pythagoras. Pythagoras adalah seorang ahli geometri dan filsuf dari Yunani. ${ }^{1}$ Tidak seperti murid-murid di Lyceum milik Aristoteles atau Academia milik Plato, para Pythagorean selain mempelajari matematika, mereka memiliki kepercayaan mistik dan tradisi yang ketat.

Beberapa konsep matematika yang dipelajari di sekolah maupun perguruan tinggi sekarang ini, lahir dari pemikiran Pythagoras. Salah satunya yang masih dipakai sampai sekarang adalah teorema Pythagoras berupa perbandingan kuadrat sisi-sisi segitiga $\left(a^{2}+b^{2}=c^{2}\right)$. Konsep matematika tersebut sampai saat ini tetap diajarkan dan dianggap sebagai sesuatu yang jauh dari hal mistik, metafisik, dan keagamaan. Oleh karena itu, menarik untuk dikaji apakah ada bentuk-bentuk religiositas dalam sekte Pythagorean terkait matematika dan jika ada, bagaimana bentukbentuk religiositas tersebut.

Saat ini matematika dikenal sebagai subjek yang bersifat nonagamis, bebas mistik, logis, sistematis, dan pasti, namun hal ini bertolak belakang dengan anggapan pada zaman peradaban kuno seperti Mesir dan Babilonia serta Yunani. Pada peradaban Mesopotamia dan Babilonia, aktivitas matematika sangat dekat dengan astrologi, sehingga antara aktivitas terkait hitung-menghitung angka dan peramalan saling berbaur. Hal yang sama juga terjadi di peradaban Mesir Kuno. Para pendeta di Mesir Kuno menggunakan matematika untuk meramalkan pasang dan surut sungai $\mathrm{Nil}^{2}$ Teknik matematika tersebut dianggap keramat sehingga hanya dimiliki oleh para pendeta dan orang-orang biasa tidak boleh mempelajarinya, bahkan ada seruan Tunequaesieris, scirenefas! (jangan bertanya, pengetahuan itu bukan untuk kita!). ${ }^{3}$ Matematika di Mesir

\footnotetext{
${ }^{1}$ Paul Davies, Membaca Pikiran Tuhan, Dasar-dasar Ilmiah dalam Dunia yang Rasional, terj. Hamzah (Yogyakarta: Pustaka Pelajar, 2002), 139.

2 Jujun S. Suriasumantri, Filsafat Ilmu: Suatu Pengantar Populer (Jakarta: Pustaka Sinar Harapan, 2009), 202.

${ }^{3}$ Ibid., 208.
} 
Kuno yang sangat erat dengan sihir dan peramalan ini dianggap suci dan tidak boleh disebar luaskan. Beberapa tradisi keagamaan seperti Kabala juga melibatkan angka sebagai salah satu ritual mereka. Hal yang sama juga terjadi di wilayah Jawa. Tradisi ngitung dalam primbon Jawa adalah suatu hal yang bersifat mistis. Dari berbagai penjabaran di atas terlihat bahwa pada awalnya matematika adalah aktivitas yang sangat berkaitan dengan suatu tradisi metafisik dan religiositas tertentu.

Pembauran dan belum adanya pemisahan yang tegas antara mistik, metafisik, dan matematika di beberapa peradaban juga terjadi di peradaban Yunani Kuno, yakni pada sekte Pythagorean. Pada zaman Pythagoras, belum ada pemisahan yang tegas antara filsafat, agama, dan matematika, walaupun pada sekarang ini objek-objek tersebut saling memisahkan diri secara rigid.

Matematika dalam tradisi Pythagorean dipandang secara berbeda dengan pemahaman matematika sekarang ini. Hal ini karena mereka memandang angka sebagai sesuatu yang sakral. Kredo mereka adalah Number rules the universe. Kredo ini merupakan suatu bentuk kepercayaan di mana mereka menempatkan angka sebagai sesuatu yang inferior dan adikuasa. Selain itu, dalam konsep kosmologi, mereka meyakini bahwa alam semesta diatur dan diciptakan (created) dengan perbandinganperbandingan (ratio). Dari sinilah kaum Pythagorean percaya bahwa alam semesta adalah sesuatu yang harmonis karena diatur dengan perbandingan-perbandingan dan angka-angka.

Kaum Pythagorean menjaga dengan ketat apa yang mereka yakini berupa kesakralan angka dan hukum perbandingan. Ide atau bentuk pemikiran yang tidak sesuai dengan konsep kepercayaan mereka akan disingkirkan demi terjaganya doktrin mereka tentang divinitas angka. Hippasus dari Metapontum yang menemukan bilangan irasional (secara harfiah bilangan yang tidak bisa diperbandingkan/di-ratio-kan) dijatuhi hukuman mati oleh para Pythagorean. Hal ini karena penemuan bilangan irasional bisa mengguncang sistem keyakinan mereka tentang kesakralan angka sebagai hakikat representasi realitas dan devine providence atas kosmos. Pythagorean percaya bahwa angka adalah ukuran bagi semua realitas, dengan kata lain, semua benda/bidang bisa diukur dan 
direpresentasikan lewat angka secara pasti. ${ }^{4}$ Namun, kepercayaan tersebut bisa dibantah dengan adanya bilangan irasional. Panjang bypotenusa dari segitiga yang sisi-sisi lainnya $1 \mathrm{~cm}$ adalah berupa bilangan irasional $(\sqrt{2})$. Artinya, kita tidak bisa menentukan secara pasti hasil dari akar dua, karena angka di belakang koma dari hasil operasi itu akan terus berlanjut dan tidak terbatas dan kuadrat dari akar dua tidak bisa diungkapkan ke dalam rasio atau perbandingan. ${ }^{5}$ Adanya bilangan irasional ini menunjukkan bahwa ada suatu bidang ukur di mana angka tidak bisa mewakili besaran dari bidang tersebut. Dengan kasus ini, Pythagorean berusaha mempertahankan dogma-dogma di dalam sektenya dari segala bentuk pemikiran yang mengancamnya.

Sekte Pythagorean merupakan suatu komunitas religi yang memiliki sistem kepercayaan akan yang sakral dan doktrin serta ritual yang selalu dijaga yang berkaitan dengan matematika. ${ }^{6}$ Kepercayaan akan divinitas angka dan pemeliharaan atas sistem kepercayaan mereka menunjukkan mereka telah memiliki sistem keagamaan yang tidak hanya bersifat individual namun sosial. ${ }^{7}$ Dari hal-hal di atas menunjukkan bahwa sekte Pythagorean tidak hanya melihat matematika sebagai suatu yang profan namun lebih ke hal-hal yang metafisik dan spiritual.

Sekte Pythagorean memang tidak memiliki konsep kenabian, kitab suci maupun penganut yang luas. Dengan perspektif tersebut, memang akan sulit mengklasifikasikan Pythagorean sebagai suatu agama. Namun sekte Pythagorean memiliki landasan-landasan teologis tahap awal di mana hal tersebut merupakan ciri dari bentuk-bentuk awal keagamaan. Oleh karena itu, berbagai bentuk kepercayaan dan ritual dari sekte Pythagorean akan dianalisis melalui teori bentuk-bentuk keagamaan dasar dari Emile Durkheim. Emile Durkheim berpendapat bahwa ada beberapa bentuk dasar (elementary) dari religiositas, yakni pembedaan atas

\footnotetext{
${ }^{4}$ Davies, Membaca Pikiran Tuhan, 139.

${ }^{5}$ Ibid., 140.

${ }^{6}$ Lihat Charles Seife, Biografi Angka Nol (Yogyakarta: E-Nusantara, 2000), 52-53.

7 Selain memiliki pandangan atas kosmos, Pythagorean merefleksikan pandangan mereka menjadi landasan moral yang mengatur hubungan mereka dengan makhluk dalam semesta. Penjelasan ini djabarkan oleh S. K Heninger, Touch of Sweet Harmony: Pythagorean Cosmology and Renaissance Poetics (California: Angelico Press, 2013), 256.
} 
yang sakral dan profan, ${ }^{8}$ yang kemudian dimanifestasikan pada ritual, totem, dan tabu. Dalam kepercayaan sekte Pythagorean, angka, perbandingan, dan bentuk-bentuk geometris dalam matematika bukan sekedar ilmu yang sekuler, namun suatu perwujudan atas Yang Sakral. Dengan landasan ini, menarik untuk dikaji bagaimana bentuk-bentuk keagamaan sekte Pythagorean terkait dengan aktivitas dan konsep matematika, berupa konsep kesakralan, ritual, totem, dan tabu yang mereka yakini melalui kacamata Durkhemian.

Tulisan ini dibagi menjadi tiga bagian. Pada bagian pertama akan dibahas makna agama menurut Durkheim dan beberapa pemikir lain. Pada bagian kedua, berupa elemen dasar keagamaan dalam pemahaman Durkheim, yang dijabarkan menjadi tiga hal. Ketiga hal tersebut adalah kepercayaan terhadap yang sakral, kepercayaan totem dalam keagamaan, dan ritual sebagai inti dari bentuk keagamaan. Bagian kedua ini adalah alat analisis yang akan digunakan untuk menganalisis religiositas sekte Pythagorean. Hasil dari analisis tersebut dijabarkan pada bagian ketiga berupa Pythagorean sebagai sebuah sekte religius. Bagian ketiga ini akan menjabarkan empat hal. Keempat hal tersebut yakni: Pertama, angka sebagai Yang Sakral, dan pembahasan angka; Kedua, bentuk geometris dan perbandingan sebagai totem dan konsep kosmos; Ketiga, tabu dalam sekte Pythagorean; Keempat akan membahas tentang ritual dalam sekte Pythagorean.

\section{Memburu Makna Agama}

Dalam pembahasan ini penulis mendefinisikan agama sebagai suatu kepercayaan kepada yang sakral, adanya konsep tabu, totem, serta ritual. Batasan tersebut diambil karena pendefinisian agama secara luas berupa kepercayaan atas hal yang supranatural akan mengurangi ketajaman analisis. Selain itu, bentuk pendefinisian agama dalam perspektif basic religion dimaksudkan agar bentuk-bentuk religiositas yang ada pada sekte Pythagorean yang cenderung bersifat elementer bisa dijelaskan dengan baik. Sekte Pythagorean tidak memiliki sistem religiositas yang kompleks dan cenderung hanya dilabeli sebagai sebuah

${ }^{8}$ Daniel L Pals, Seven Theories of Religion (Yogyakarta: Diva press, 2011), 145. 
kelompok spiritual dari tradisi agama Yunani karena hanya memiliki bentuk-bentuk dasar dari sistem keagamaan. Dengan menganggap agama adalah sistem kompleks yang memiliki konsep ketuhanan, kenabian, kitab suci, aturan yang rigid dan pengikut yang jelas, akan sulit menemukan unsur-unsur keagamaan dalam sekte Pythagorean ini. Sehingga, untuk melihat bagaimana sistem religiositas dalam sekte Pythagorean perlu sebuah analisis yang bisa mengkaji bentuk-bentuk dasar tersebut. Atas alasan di atas, kepercayaan yang bersifat elementer dalam sekte Pythagorean tersebut akan dianalisis dengan perspektif Durkhemian tentang bentuk-bentuk dasar keagamaan.

E.B. Taylor memberi pengertian tentang agama sebagai "keyakinan pada sesuatu yang spiritual". Lebih lanjut Taylor menjelaskan bahwa esensi semua agama adalah Animisme, berasal dari kata Anima yang berarti ruh. Pengertian yang diberikan Taylor cukup bisa memberi pemahaman tentang apa itu agama, namun definisi ini terlalu luas untuk bisa menjelaskan suatu sistem keyakinan. Suatu agama merupakan sistem yang mengikat dan muncul dalam suatu masyarakat, sehingga definisi yang diberikan Taylor lebih cenderung pada spiritualitas yang bersifat personal, bukan sosial.

Dalam pemahaman dan definisi agama yang dianut dalam konstitusi di Indonesia yang mensyaratkan adanya empat unsur di mana suatu bentuk religiositas bisa dimaknai sebagai agama, yakni adanya kepercayaan terhadap keesaan Tuhan, adanya kitab suci, adanya konsep kenabian, dan mempunyai peraturan tentang way of life yang jelas. ${ }^{10}$ Definisi tersebut lebih cenderung merujuk pada tradisi agama-agama Abrahamik, sehingga bentuk religiositas yang lebih bersifat basic atau elementer akan sulit dijelaskan dan sulit dikelompokkan sebagai agama melalui konsep tersebut.

Dalam sekte Pythagorean tidak ditemukan adanya konsep kitab suci dan kenabian, seperti konsep dalam agama Abrahamik. Namun,

\footnotetext{
${ }^{9}$ Ibid., 140.

${ }^{10}$ Untuk penjelasan bagaimana kritik wacana kata "agama" dianalisa secara sosio-politik serta bagaimana kata tersebut dikonstruksi oleh Negara, lihat Sita Hidayah, "The Politics of Religion Invention of "Agama" in Indonesia", dalam Kawistara, Vol. 2, No. 2 (Desember, 2012), 9.
} 
bukan berarti elemen-elemen religiositas dalam sekte Pythagorean tidak bisa ditangkap sebagai bentuk keagamaan. Dalam tulisan ini akan dianalisis sistem keagamaan sekte Pythagorean berupa konsep pembedaan akan yang sakral dan profan, penggunaan konsep tabu dan totem dalam ritualritual terutama dalam ruang lingkup tradisi matematika mereka. Atas tujuan tersebut berikut akan dijabarkan pemikiran Durkheim terkait bentukbentuk keagamaan dasar.

\section{Elemen dasar keagamaan dalam pemahaman Durkheim}

Durkheim memberikan penjelasan bahwa walaupun bentukbentuk keagamaan beraneka ragam, tetapi tiap agama memiliki bentukbentuk dasar yang umum dimiliki oleh setiap agama, yakni pembedaan antara yang sakral dan yang profan, ide tentang jiwa, roh, sosok-sosok mistis, divinitas kebangsaan maupun antar bangsa yang termanifestasi pada totem-totem, ritual negatif berupa tabu, dan ritual positif. ${ }^{11}$ Elemenelemen tersebut adalah sesuatu yang menjadi dasar pembentukan sistem keagamaan yang lebih kompleks. Melalui elemen-elemen tersebut, bentuk religiositas sekte Pythagorean akan dianalisa, sehingga akan bisa dijabarkan bagaimana bentuk-bentuk religiositas yang ada pada sekte Pythagorean tersebut.

\section{Kepercayaan terhadap Yang Sakral}

Taylor dan Frazer melihat bahwa agama dalam suatu sistem masyarakat adalah sesuatu yang berkaitan dengan yang supranatural, namun Durkheim tidak berpendapat bahwa masyarakat primitif memiliki konsep tentang dikotomi dua hal tersebut. Durkheim berasumsi bahwa masyarakat primitif sebenarnya tidak membedakan adanya dunia natural dan supranatural. ${ }^{12}$ Dalam masyarakat ini, mitos yang ada merupakan penjelasan atas fenomena alam yang mereka temui. Mitos merupakan sebuah sarana pemikiran yang bisa memberi arti atas dunia yang sulit mereka pahami. Oleh karena itu, Durkheim memiliki pandangan yang berbeda dengan Taylor dan Frazer terhadap bagaimana menjelaskan

${ }^{11}$ Lihat Emile Durkheim, The Elementary Forms of The Religious Life (Yogyakarta: Diva Press, 2011), 593.

12 Ibid., 144. 
religiositas, di mana ia lebih menekankan kepercayaan akan yang sakral sebagai suatu ciri keagamaan.

Hal sakral tersebut adalah yang menjadi acuan bagaimana sistem dalam masyarakat yang terbentuk, baik larangan-larangannya maupun berbagai ritual yang harus dilakukan. Dalam pemahaman Durkheim, hal sakral diartikan sebagai sesuatu yang superior, berkuasa dalam kondisi normal, dia tidak tersentuh dan selalu dihormati. ${ }^{13}$ Sistem keagamaan adalah sebuah struktur dalam dunia sosial yang mencoba mempertahankan apa yang sakral baik melalui ritual-ritual yang melibatkan totem maupun larangan atau tabu yang harus dipatuhi. Sebagaimana diutarakan oleh Durkheim bahwa agama adalah suatu sistem kepercayaan dengan perilaku-perilaku yang utuh dan selalu dikaitkan dengan yang sakral, yaitu sesuatu yang terpisah dan terlarang. ${ }^{14}$ Dengan pemisahan yang sakral dan yang profan sebagai fondasi, konsepkonsep dan bentuk-bentuk keagamaan yang lain terbentuk.

2. Kepercayaan Totemik dalam Keagamaan

Salah satu elemen dasar dari bentuk-bentuk keagamaan menurut Durkheim adalah kepercayaan terhadap totem dan fungsinya dalam membentuk sistem keagamaan. Durkheim menilai bahwa totem berfungsi sebagai simbol klan atau kelompok dan pembeda atas yang sakral dan yang profan. ${ }^{15}$ Selain itu, totem merupakan salah satu pusat ritual masyarakat. Serta fungsi utama lainnya adalah sebagai pembentuk persepsi atas kosmos. Dengan berbagai fungsi tersebut, membuat totem menjadi salah satu inti dari bentuk-bentuk religiositas dasar.

Totem adalah archetype utama dari hal-hal yang sakral, maka pembedaan antara yang profan dan sakral berdasarkan atas totem tersebut. ${ }^{16}$ Totem secara sederhana bisa dimaknai sebagai suatu lambang dari suatu klan atau kelompok tertentu. Totem biasanya berupa binatang,

\footnotetext{
13 Ibid., 145.

14 Ibid., 145.

15 Lihat penjabaran Deniel Pals mengenai pendapat Durkheim atas totem dalam Seven Theories of Religion (Yogyakarta: Diva press, 2011), 148-160.

${ }^{16}$ Emile Durkheim, The Elementary Forms of The Religious Life (Yogyakarta: Diva Press, 2011), 178.
} 
yang merupakan perwujudan dari yang sakral dan merupakan lambang dari suatu klan, namun totem juga bisa berupa benda atau hal apa pun yang memiliki keistimewaan. Totem biasanya bersifat individual, namun bisa berupa spesies burung gagak, atau kangguru secara umum. ${ }^{17}$ Oleh karena itu, hewan yang dijadikan totem tidak boleh diburu dan dihormati oleh anggota masyarakat. ${ }^{18}$ Hewan-hewan yang bukan totem bisa diburu dan dimakan karena mereka bersifat profan. Sedangkan hewan totem, yang merupakan Yang Sakral, akan dihormati dan dipuja. Bisa juga, totem merupakan sesuatu yang memiliki keanehan, kemungkinan akan dijadikan sebagai totem. Dengan adanya totem ini masyarakat bisa memaknai mana realitas keagamaan dan mana yang bukan realitas keagamaan.

Sebagai penghubung dengan Yang Sakral, totem merupakan pusat pelaksanaan ritual-ritual. Para pemuja totem sebenarnya tidak menyembah para binatang tersebut, namun yang mereka sembah adalah suatu kekuatan yang gaib dan anonym dan impersonal yang dapat ditemukan dalam binatang-binatang tersebut. ${ }^{19}$ Sebagaimana dijelaskan Durkheim bahwa totem tersebut digunakan dalam ritual upacara. Namun hakikatnya, dalam masyarakat suku, ritual-ritual atas totem bukan merupakan suatu penyembahan terhadap hewan totem tersebut, namun merupakan pemujaan akan suatu entitas tertinggi yang misterius yang ada pada totem tersebut. Ritual-ritual untuk pemujaan Yang Sakral tersebut digelar, sehingga masyarakat sebagai anggota klan dengan totem tersebut memiliki rasa kepemilikan dan kesatuan. Pemujaan atau ritual dengan Yang Sakral inilah yang membentuk ikatan berbagai individu dalam sebuah masyarakat.

Totem tidak sekedar simbol, namun merupakan konsep dan pemahaman yang memberikan persepsi atas dunia. Hal ini karena totem merupakan bentuk persepsi dasar atas pemahaman alam. ${ }^{20}$ Totem berfungsi sebagai landasan epistemologi bagaimana alam dipahami oleh

\footnotetext{
17 Ibid., 148.

${ }^{18}$ Lihat Pals. Seven Theories, 148.

${ }^{19}$ Ibid., 150.

${ }^{20}$ Ibid., 149.
} 
masyarakat, karena totemisme juga memiliki sistem kosmologi. ${ }^{21}$ Di sini, totem tidak hanya digunakan untuk mengklasifikasikan berbagai marga ke dalam klan-klan tertentu yang memiliki totemnya masing-masing. Totem tidak hanya mengklasifikasikan masyarakat, namun juga bendabenda yang ada di alam. Untuk memahami tentang kosmos, berbagai benda di alam, baik bumi, bintang, awan, dan pohon dikelompokkan ke dalam totem tertentu dengan sifatnya masing-masing. Dengan pengelompokan terhadap totem tertentu, alam bisa dipahami, sehingga totem berfungsi sebagai perspektif akan kosmos dengan cara melakukan klasifikasi atas benda-benda yang ada di alam.

\section{Ritual sebagai Inti dari Bentuk Dasar Keagamaan}

Elemen dasar yang sangat penting dalam suatu bentuk keagamaan adalah ritual, karena dengan ini, masyarakat akan terbentuk. Ritual dipandang jauh lebih penting dari keyakinan atas totem ${ }^{22}$ karena fungsi ritual tidak hanya untuk memisahkan antara yang sakral dengan yang profan, namun mampu membuat setiap individu tergiring kepada yang sakral dan memiliki kesamaan dan kesatuan dalam sebuah masyarakat. Menurut Durkheim, secara definisi, yang disebut sakral adalah apa-apa yang disisihkan, yang diletakkan terpisah. ${ }^{23}$ Pemisahan dan kuterputusan inilah yang membedakan dengan yang profan. Ritual menjadi inti terpenting dalam sistem keagamaan karena ritual mampu membentuk ikatan antar individu yang akhirnya membentuk sebuah kesatuan komunitas atau masyarakat.

Lebih lanjut, Daniel Pals menjelaskan bahwa ritual dibagi menjadi dua, ritual positif dan ritual negatif, namun ada juga di luar keduanya yang disebut dengan ritual yang aneh, khas, tidak biasa (peculiar). ${ }^{24} \mathrm{Pals}$ menjelaskan bahwa ritual bentuk pertama adalah berupa laranganlarangan atau tabu. Ritual bentuk kedua bertujuan untuk kesenangan dan kegembiraan yang bisa mengikat setiap anggota kelompok ke dalam kesatuan komunitas. Sedangkan ritual yang ketiga berfungsi sebagai penebusan dosa dan menghindar dari berbagai hal buruk.

${ }^{21}$ Durkheim, The Elementary Forms, 223.

22 Pals, Seven Theories, 156.

${ }^{23}$ Durkheim, The Elementary Forms, 434.

${ }^{24}$ Pals, Seven Theories, 157. 
Ritual negatif berkaitan dengan tabu, atau apa yang dilarang dalam masyarakat. Dengan larangan ini, masyarakat akan terpisah dengan hal-hal profan. Tujuan utama dari tabu tersebut adalah menjauhkan dari hal buruk dan profan serta mendekatkan setiap individu pada yang sakral. Durkheim menyebut orang-orang yang menjaga diri dari tabu sebagai orang asketis, yakni orang yang dengan sekuat tenaga menolak keinginan dan nafsu dalam dirinya sendiri. ${ }^{25}$ Salah satu contoh tabu dalam agama dunia adalah larangan untuk beraktifitas di hari-hari tertentu, seperti hari Sabat pada tradisi Yahudi.

Dengan ritual-ritual tersebut, setiap individu akan hanyut pada suasana dan nuansa yang dibangun. Durkheim menyebutnya effervescent moment, yakni suatu masa di mana tiap individu memiliki satu tujuan, rasa, pandangan, gairah yang sama pada satu titik. Tiap individu yang mengikuti ritual tersebut hanyut pada perasaan Yang Sakral. Pada titik inilah individu-individu yang ada melebur menjadi satu kesatuan. Di sinilah masyarakat terbentuk! Secara ringkas, Durkheim berpendapat bahwa inti dari bentuk keagamaan berada pada ritual, karena ritual inilah yang membentuk perasaan-perasaan spiritual muncul pada diri tiap individu, sehingga kesadaran akan pentingnya klan dan kelompok akan tumbuh. ${ }^{26}$ Oleh karena itu, kegiatan-kegiatan ritual ditujukan untuk menumbuhkan rasa keagamaan di mana perasaan yang muncul tersebut adalah bagian dari yang sakral. Atas pemahaman ini, akan dianalisa bagaimana bentuk-bentuk ritual dan fungsinya dalam konsep keagamaan sekte Pythagorean.

\section{Sekte Religius Pythagorean}

Sekte Pythagorean adalah kelompok religius-intelektual pengikut Pythagoras. Kelompok ini didirikan di daerah selatan Italia sekitar tahun 525 SM. $^{27}$ Sedangkan Pythagoras sendiri adalah seorang filsuf Yunani

\footnotetext{
25 Ibid., 157.

26 Ibid., 158.

27 Holger Thesleff, "Pythagoreanism", dalam, http://www.britannica.com/ EBchecked/topic/485235/Pythagoreanism, 21 Februari 2013/diakses 20 September 2014.
} 
yang kontroversial dan terkenal. Pythagoras hidup sekitar 570 sampai 490 SM. Ia berasal dari Samos. Pada sekitar umur empat puluhan ia pindah ke daerah Croton, Italia selatan, dan di sanalah ia banyak melakukan aktivitas filsafatnya, termasuk mendirikan sekte Pythagorean. ${ }^{28}$ Sekte Pythagorean bukan sekedar kelompok intelektual atau sekolah layaknya Academia atau Lyceum. Pythagorean merupakan sekelompok yang memiliki rasa persaudaraan yang erat dan memiliki tradisi serta ritual yang dijalankan secara ketat. Walaupun kaum Pythagorean ini mengikuti tradisi agama Yunani yang menyembah banyak dewa di kuil-kuil mereka, namun Pythagorean memiliki sistem ketuhanan dan tradisi yang berbeda dengan masyarakat Yunani pada umumnya. ${ }^{29}$

Sistem ketuhanan dan ritual yang ada pada sekte Pythagorean memang tidak selengkap agama-agama besar dunia seperti Budha dan Hindu atau tradisi agama Abrahamik, namun mereka memiliki dasardasar sistem religiositas yang jelas. Oleh karenanya, anggapan yang mengatakan bahwa Pythagorean bukanlah sebuah agama karena tidak memiliki sistem yang spesifik dan hanya merupakan sebuah pandangan hidup yang lebih menekankan pada tradisi Yunani adalah sebuah kekeliruan. ${ }^{30}$ Pythagorean memang tidak memiliki teks suci, konsep kenabian, dan ritual-ritual yang kompleks. Namun, bentuk-bentuk elementer keagamaan seperti konsep yang sakral, totem, dan tabu muncul dalam tradisi sekte Pythagorean ini.

Sejak kematian Pythagoras, para pengikutnya tercerai-berai namun pemikirannya merefleksi pada pemikiran Plato dan Aristoteles. ${ }^{31}$ Sampai sekarang pemikiran Pythagoras baik dalam matematika maupun filsafat masih terasa di dunia Barat. Seperti kematian Hippasus yang misterius, kematian Pythagoras juga menjadi polemik. Ada yang berpendapat bahwa Pythagoras dibunuh oleh musuh-musuhnya bersama dengan para pengikutnya. Walaupun tidak meninggalkan tulisan,

\footnotetext{
${ }^{28}$ Carl Huffman, "Pythagoras," dalam http://plato.stanford.edu/entries/ pythagoras, 23 Februari 2005/diakses 20 September 2014.

29 Thesleff, "Pythagoreanism".

${ }^{30}$ Huffman,"Pythagoras".

${ }^{31}$ Seife, Biografi Angka, 54.
} 
pemikiran Pythagoras sangat mempengaruhi para filsuf Yunani setelahnya bahkan sampai ke pemikiran Copernicus dan Galileo.

\section{Angka sebagai Yang Sakral}

Dalam sekte Pythagorean, angka menjadi pemahaman sentral sebagai sesuatu yang sakral. Number rule the universe adalah doktrin utama yang diyakini oleh Pythagoras dan pengikutnya. ${ }^{32}$ Mereka memandang angka sebagai the ultimate being dan perwujudan atas kesempurnaan yang penjaga alam semesta. Harmoni angka terwujud dalam perbandinganperbandingan yang membentuk alam semesta, sehingga angka dalam pemahaman Pythagorean merupakan sebagai inti tertinggi atas realitas dan sebagai perwujudan dari Yang Sakral.

Sebagaimana diutarakan Heninger bahwa salah satu pilar utama dalam doktrin Pythagorean adalah kepercayaan bahwa angka merupakan hakikat tertinggi atas unsur pokok realitas. ${ }^{33}$ Atas konsep ini, Pythagorean menjadi sangat antusias dalam mendalami teori bilangan dan geometri. Dalam pandangan Durkheim, kaum Pythagorean mencoba melakukan pemisahan atas apa yang sakral dan yang profan. Seperti yang telah dijelaskan di atas bahwa salah satu bentuk keagamaan dasar adalah kepercayaan akan yang sakral. Dalam hal ini, angka adalah perwujudan yang sakral bagi kaum Pythagorean. Pada pemahaman akan konsep inilah kaum Pythagorean tengah membentuk sistem religiositas mereka. Yang Sakral adalah entitas yang terpisah dari hal-hal yang biasa.

Pythagorean berpendapat bahwa realitas tertinggi berada pada dunia pikiran bukan pada realitas fisik, sehingga realitas yang berubahubah muncul pada alam semesta dan bisa dihubungkan dengan realitas yang absolut (pikiran), dengan analisis yang rasional. ${ }^{34}$ Walaupun mereka melihat adanya dikotomi dunia, namun ada keterkaitan antara keduanya. Dengan memahami hakikat konsep-konsep matematika sebagai realitas absolut, mereka bisa memahami bagaimana dunia fisik bekerja sesuai irama harmoni matematika. Harmoni dan keteraturan angka yang

\footnotetext{
32 Ibid., 38. Lihat juga Davies, Membaca Pikiran Tuban, 139.

${ }^{33}$ Heninger. Touch of Sweet, 71.

${ }^{34}$ Ibid., 74.
} 
terwujud pada alam semesta merupakan pemahaman kosmologi dari sekte Pythagorean.

Selain divinitas angka, Pythagorean juga memiliki kepercayaan yang bersifat mistik terhadap angka, di mana angka mewakili realitas tertentu. Sebagai contoh, bilangan genap yang bisa dibagi menjadi dua bagian sama banyak melambangkan lemahnya kesatuan dan perpecahan. Sedangkan bilangan ganjil tidak bisa dibagi dua, bilangan ini melambangkan keilahian, keutuhan dan kesempurnaan. ${ }^{35}$ Contoh lain adalah angka 1 yang mewakili akal, 2 yang mewakili pria, angka 3 yang mewakili wanita dan angka 5 yang mencerminkan perkawinan karena gabungan 2 (pria) dan 3 (wanita). ${ }^{36}$

Bentuk kepercayaan atas kesakralan angka dalam sekte Pythagorean menunjukkan bahwa Pythagorean memiliki sistem religius. Pythagorean memandang angka tidak sekedar wakil atas realitas, namun sebagai perwujudan akan Yang Sakral. Secara sederhana, Pythagoras mendefinisikan godhead sebagai angka. ${ }^{37}$ Sebagaimana dalam pemikiran Durkheim, kepercayaan akan konsep yang sakral merupakan salah satu bentuk dasar keagamaan. Sebagai realitas tertinggi, angka memberi pandangan bagaimana dunia bekerja dan bagaimana dunia diatur dalam keharmonisan.

\section{Bentuk Geometris dan Perbandingan Angka sebagai Totem dan Konsep Kosmos}

Kaum Pythagorean berpendapat bahwa kunci untuk memahami alam semesta adalah pada angka dan perbandingan. Oleh karena itu, kaum Pythagorean sangat serius dalam menghabiskan banyak energi dalam bergulat dengan matematika. ${ }^{38}$ Teorema Pythagoras adalah salah satu bentuk perbandingan yang sangat populer, disamping itu ada juga banyak bentuk perbandingan lain. Salah satu yang sangat fenomenal adalah perbandingan yang disebut dengan "perbandingan emas" (golden

\footnotetext{
${ }^{35}$ Ibid., 86.

36 The Liang Gie, Filsafat Matematik (Yogyakarta: Penerbit Supersukses, 198), 13.

${ }^{37}$ Heninger, Touch of Sweet, 201.

38 Seife, Biografi Angka, 44.
} 
ratio) yang sangat diagung-agungkan sekte Pythagorean. Pythagorean berpendapat bahwa alam semesta dibentuk dengan perbandinganperbandingan. Salah satu gagasan utama mereka tentang alam semesta adalah perbandingan emas. Untuk mendapatkan perbandingan emas kita perlu membagi sebuah garis atau bidang dengan cara khusus; bagi garis tersebut menjadi dua bagian sehingga perbandingan antar bagian yang pendek dan bagian yang panjang sama dengan perbandingan antara bagian yang panjang dengan panjang keseluruhan. ${ }^{39}$

\section{Gambar 1}

Perbandingan Emas ${ }^{40}$

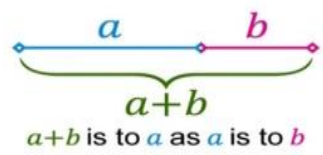

Perbandingan tersebut memang terlihat sederhana, namun replika atas perbandingan tersebut banyak ditemui di alam semesta. Sebagai contoh adalah perbandingan ukuran cangkang siput, ukuran wajah dan ukuran bentuk bunga. Pythagorean percaya bahwa berbagai hal di alam semesta ini dibentuk dengan perbandingan-perbandingan yang sesuai dengan harmoni dan keindahannya. ${ }^{41}$ Oleh karena itu, banyak bangunan dan karya seni klasik yang terkenal menggunakan bentuk dasar perbandingan emas dalam menentukan rancangannya. Bagi Pythagorean, memahami matematika adalah sebuah bentuk penyatuan dan pemahaman akan alam, karena memahami alam semesta tersusun melalui perbandingan-perbandingan dan angka matematis.

Kaum Pythagorean sangat tertarik dengan geometri. Mereka melihat adanya kesatuan antara angka dan bentuk di mana setiap angka mewakili bentuk geometris tertentu. Tidak seperti bangsa Mesir yang menggunakan geometri untuk mengukur lahan, Pythagoras dan pengikutnya memandang bentuk geometris secara lebih "mendalam". Ini karena angka dan bentuk adalah saling berkelindan, bentuk geometris

\footnotetext{
${ }^{39}$ Ibid., 40.

${ }^{40}$ Garis lurus yang terbagi menjadi a dan b, di mana perbandingan emas adalah a:b sama dengan a:a+b. Sumber gambar diambil dari http://en.wikipedia.org/wiki/Golden_ratio

${ }^{41}$ Lihat Seife, Biografi Angka, 49.
} 
tertentu juga memberikan konsep akan kosmologi bagi kaum Pythagorean. Secara singkat, Herninger meringkas pemahaman sekte Pythagorean tentang bentuk dan kosmologi dalam satu paragraf dalam bukunya, ia berpendapat bahwa:

Pythagoras membagai dunia menjadi dua dikotomi, yakni realitas ide dan realitas fisik. Penciptaan merupakan suatu hal yang ada di alam materi atau fisik. Pemahaman atas prinsip-prinsip utama tergantung pada hubungan antara pikiran dan materi. Interaksi antara dua hal tersebut termaktub pada geometri. Unit-unit dalam geometri membentuk garis, lalu bidang datar dan akhirnya ruang tiga dimensi. Dari hal tersebut memungkinkan adanya kualitas dasar yakni, panas, dingin, basah dan kering. Dari kondisi tersebut terbentuklah empat elemen dasar yakni udara, bumi, air dan api. ${ }^{42}$

\section{Gambar 2.}

Bentuk Geometris yang Istimewa ${ }^{43}$

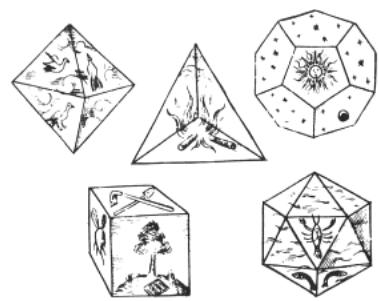

Ini menunjukkan bahwa Pythagorean memiliki konsep tentang kosmologis yang sarat akan materi geometri dan perbandingan. Dengan konsep-konsep matematika tersebut, pemahaman mendasar akan kosmos bisa dijabarkan oleh mereka. Menurut sekte Pythagorean, keempat bentuk elemen dasar berupa udara, bumi, air, dan api direpresentasikan ke dalam bentuk geometris. Octohedron mewakili udara, tetrahedron mewakili api, kubus menggambarkan bumi, dan icosahedrons menggambarkan udara. ${ }^{44}$ Sebetulnya, nilai dasar dari numeric dan bentuk geometris ini bukan ke-masuk-akal-annya, tetapi pada fakta bahwa

\footnotetext{
${ }^{42}$ Heninger, Touch of Sweet, 207.

${ }^{43}$ Sumber gambar diambil dari Heninger, Touch of Sweet, 108.

${ }^{44}$ Ibid., 108-109.
} 
Pythagorean membicarakan dunia fisik/realitas sebagai manifestasi dari hubungan-hubungan matematik yang harmonis. ${ }^{45}$

Sama seperti masyarakat religius yang dijelaskan Durkheim, mereka mengambil sesuatu sebagai totem karena memiliki karakteristik yang spesial. Kelima bentuk geometris tersebut juga memiliki sifat khusus, yakni semua panjang sisi dari lima bentuk tersebut adalah sama. ${ }^{46}$ Selain itu, mereka percaya bahwa kelima unsur tersebut merupakan unsur dasar pembentuk alam semesta, tidak hanya dalam kualitasnya berupa udara, bumi, air, dan api, namun perbandingan ukuran yang ada pada bentuk geometris tersebut. Sehingga tidak mengherankan jika kaum Pythagorean menjadikan bentuk geometris tersebut sebagai konsepsi yang sakral atas kosmos. ${ }^{47}$

\section{Gambar 3:}

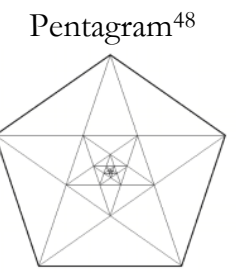

Lambang sekte Pythagorean adalah sebuah pentagram, yakni bintang dalam pentagon (segi lima). ${ }^{49}$ Bisa dikatakan bahwa pentagram ini adalah salah satu totem dalam sekte mereka. Hal ini karena pentagram berfungsi sebagai lambang sekte yang bersifat sakral dan juga merupakan pandangan atas kosmos. Pentagram adalah perpaduan antara bentuk dan perbandingan angka. ${ }^{50}$ Jika garis-garis dihubungkan yang terdapat di setiap ujung pentagon itu dihubungkan, akan terbentuk sebuah bintang sudut lima dengan proposisi atau perbandingan yang sama, bintang tersebut memiliki pentagon juga di dalamnya yang lebih kecil, dan

\footnotetext{
${ }^{45}$ Davies, Membaca Pikiran, 142.

${ }^{46}$ Lihat penjelasan tentang regular solid (bidang tiga dimensi yang memiliki sisi dan sudut yang sama) dalam Heninger, Touch of Sweet, 107.

47 Ibid., 107-108.

48 Sumber gambar dari Seife, Biografi Angka, 39.

${ }^{49}$ Ibid., 39.

${ }^{50}$ Ibid.
} 
pentagon tersebut memiliki bintang juga di dalamnya, serta terus menerus tidak ada habisnya. ${ }^{51}$ Pythagorean melihat ini sebagai lambang akan ketidakterhinggaan. Namun, yang membuat pentagram ini menjadi sakral adalah apa yang tersembunyi dibalik garis-garis tersebut. Garisgaris dalam pentagram tersebut memiliki ukuran di mana perbandingannya adalah perbandingan yang diagung-agungkan oleh Pythagorean dan merupakan gagasan akan konsep kosmologi mereka, yakni perbandingan emas. ${ }^{52}$

Ini artinya, kaum Pythagorean melihat angka, bentuk geometris dan perbandingan tidak hanya sebagai sesuatu yang sakral, namun sebagai totem dan sekaligus pembentuk pemahaman atas kosmos. Hal ini senada dengan yang dijelaskan Durkheim bahwa totem dalam masyarakat adalah lambang dari yang sakral yang sekaligus menentukan persepsi atas dunia.

\section{Tabu dalam Sekte Pythagorean}

Tabu yang harus dihindari untuk dilakukan dalam sekte Pythagorean adalah mendebat sistem kepercayaan mereka terkait angka. Bagi mereka, angka adalah refleksi sempurna atas realitas dan segala sesuatu dalam alam semesta dibentuk berdasarkan perbandingan. Seperti yang telah dijelaskan sebelumnya, bahwa angka, perbandingan, dan bentuk geometris tertentu dipandang sebagai Yang Sakral dan merupakan suatu totem, sehingga perlu adanya suatu ritual negatif berupa tabu untuk melindungi kesakralan mereka. Sebagaimana diketahui bahwa banyak tabu dalam sekte Pythagorean, seperti hanya boleh makan makanan yang mentah, hanya minum air putih, tidak boleh memakan buncis, serta tidak boleh menggunakan pakaian berbahan wol. ${ }^{53}$ Namun, ide tentang bilangan irasional yang dibawa Hippasus dari Metapontum merupakan gagasan yang bisa merusak tatanan kepercayaan sekte Pythagorean. Oleh karena itu, sekte Pythagorean berusaha

\footnotetext{
${ }^{51}$ Ibid.

52 Ibid.

${ }^{53}$ Ibid., 38.
} 
mempertahankan kesakralan angka mereka dengan menghukum mati Hippasus.

Kaum Pythagorean dikenal sebagai kelompok religius yang sangat ketat dalam menjalankan pantangan-pantangan mereka. ${ }^{54}$ Kehidupan mereka sangat asketis, karena mereka hidup dengan sangat sederhana. Mereka percaya akan reinkarnasi bahwa jiwa akan berpindah ke makhluk hidup lain setelah menjalani kematian..$^{55}$ Oleh karena itu, Pythagorean dilarang untuk menyakiti setiap bentuk makhluk hidup. Karena hal ini juga, mereka tidak memakan buncis, karena terlihat seperti bentuk alat kelamin pria. $^{56}$ Berbagai pantangan baik dalam gaya hidup maupun makanan ditujukan untuk menjaga kesucian jiwa mereka. Sebagaimana yang diutarakan Durkheim tentang asketisme bahwa para penganut agama berusaha untuk menahan diri dari setiap keinginan atau hasrat yang ada pada dirinya, sehingga bisa masuk ke dalam kesakralan. ${ }^{57}$

Selain tabu di atas, Pythagorean sangat anti dengan bid'ah dalam bentuk pemikiran yang melawan keilahian angka. Pythagorean percaya adanya keterhubungan yang niscaya antara bentuk dalam realitas dan angka. Angka diyakini sebagai realitas tertinggi yang merepresentasikan segala macam bentuk dan segala bentuk dalam alam semesta ini dikonstruksi dengan perbandingan. Namun, adanya bilangan irasional menunjukkan bahwa ada suatu bentuk ukuran yang tidak bisa direpresentasikan lewat angka secara tepat dan ada sesuatu yang tidak bisa untuk diperbandingkan.

Contoh dari bilangan irasional adalah panjang hipotenusa (sisi miring) pada segi tiga siku-siku. ${ }^{58}$ Sebagai contoh, tinggi dan alas suatu segitiga adalah $1 \mathrm{~cm}$, menurut teorema pythagoras panjang sisi miringnya adalah akar dari jumlah kuadrat kedua sisi yang lainnya yakni $\sqrt{2}$. Panjang

\footnotetext{
54 Ibid, Seife, Biografi Angka, 37-38. Lihat juga penjabaran Charles H. Kahn dalam Pythagoras and The Pythagorean: A Brief history, 7-9. Dalam buku tersebut, Kahn mengatakan bahwa Pythagoras mengaku bahwa dirinya adalah reinkarnasi dari Euphorbus, seorang pahlawan dalam perang troya.

55 Ibid., 5.

56 Ibid., Seife, Biografi Angka, 37.

${ }^{57}$ Lihat Pals, Seven Theories, 157.

${ }^{58}$ Lihat Siefe, Biografi Angka, 50.
} 
hipotenusa yang sejumlah akar dari dua tersebut adalah bilangan irasional, karena kita tidak akan pernah bisa menghitung secara akurat atau pasti berapa hasil dari akar dua tersebut. Jika kita hendak mengukur hipotenusa tersebut dengan sebuah mistar biasa, kita akan mendapati angka $141 \mathrm{~mm}$, namun jika kita cermati, ternyata tidak tepat $141 \mathrm{~mm}$, tapi lebih sedikit. Untuk mengetahui berapa lebihnya, kita perlu menggunakan alat ukur yang lebih akurat. Jika kita mengukur menggunakan jangka sorong atau millimeterskrup, kita akan mendapati angka 141, $421 \mathrm{~mm}$. Jika dengan alat yang lebih teliti lagi, akan lebih banyak mendapatkan angka di belakang koma tersebut. ${ }^{59}$ Namun, angka di belakang koma tersebut akan selalu muncul dan muncul lagi. ${ }^{60}$ Artinya kita tidak bisa mengukur secara tepat berapa panjang hipotenusa tersebut, sampai kapan pun. Hal ini menunjukkan bahwa ada suatu realitas atau ukuran yang tidak bisa direpresentasikan lewat angka. Dari hal ini bisa disimpulkan bahwa sisi-sisi segitiga tersebut tidak bisa dibandingkan/di-ratio-kan. ${ }^{61}$ Sayangnya, bilangan irasional ini terdapat pada inti pokok ajaran Pythagorean, yakni teorema Pythagoras, lambang sekte mereka dan bahkan perbandingan emas. Kedua perbandingan itu adalah bilangan irasional. ${ }^{62}$

Dengan munculnya bilangan irasional, membuat sistem kepercayaan Pythagorean menjadi terancam. Oleh karena itu, Hippasus dari Metapontum dihukum mati karena menggoyahkan konsep kepercayaan tentang kesucian angka. ${ }^{63}$ Secara historis, bagaimana hukuman yang diterima oleh keduanya sangat simpang siur, namun ada yang mengatakan bahwa mereka berdua dihukum mati dengan ditenggelamkan ke laut. Dari hal ini bisa terlihat bagaimana kaum

\footnotetext{
${ }^{59}$ Siefe dengan contoh yang berbeda, juga memberikan penjabaran tentang bagamana suatu ukuran tidak bisa diperbandingkan, yakni dengan menunjukan bahwa segala bentuk usaha pengukuran tidak akan bisa mencapai titik akuran pada suatu diagonal segitiga dengan sisi-sisi yang sama. Ibid., 51-52.

${ }^{60}$ Ini adalah ciri dari bilangan irasional yang diajarkan di sekolah bahwa nilai yang dihasilkan adalah suatu angka yang tidak beraturan dan tidak terhingga (infinit). Contoh lain bilangan irasional adalah nilai pi, berupa $3.14159265358979323846 \ldots$, di mana angka dibelakang koma akan berlanjut takterhingga dan tidak memiliki pola.

${ }^{61}$ Ibid., 51.

${ }^{62}$ Ibid., 52.

${ }^{63}$ Ibid., 53.
} 
Pythagorean mempertahankan apa yang mereka anggap sebagai Yang Sakral. Karena menurut Durkheim, tujuan dari tabu adalah menjaga pemisahan antara yang sakral dan yang profan, sehingga yang sakral akan selalu terjaga dari hal-hal yang profan tersebut. Dari kasus ini terlihat bahwa Pythagorean berusaha melindung kesakralan sistem angka dan perbandingan mereka dari yang profan.

\section{Ritual dalam Sekte Pythagorean}

Durkheim berpendapat bahwa ritual positif yang bertujuan untuk kesenangan dan kegembiraan bisa mengikat setiap individu dalam kelompok ke dalam kesatuan komunitas. Hal ini juga terjadi pada sekte Pythagorean yang melakukan ritual-ritual tersebut sebagai bentuk atas penyatuan setiap individu pada sekte mereka. Sebagai komunitas yang hidup dalam masyarakat Yunani, sekte Pythagorean melakukan hal yang sama seperti orang Yunani pada umunya, yakni pergi ke kuil para dewa dan melakukan pemujaan. ${ }^{64}$ Namun sebagai sebuah sekte, para pengikut Pythagoras memiliki sistem religiositas yang unik dan berbeda dengan kepercayaan masyarakat Yunani. Sekte Pythagorean memiliki konsep sendiri tentang yang sakral, sistem totem, dan tabunya sendiri, maka sebetulnya sekte Pythagorean tidaklah sama dengan agama Yunani. Karena memiliki konsep religiositasnya sendiri, maka mereka juga memiliki ritual-ritual khusus yang hanya dilakukan oleh kelompok mereka saja.

Salah satu ritual khusus yang dilakukan sekte Pythagorean adalah "khotbah" dari Pythagoras kepada para pengikutnya. Kaum Pythagorean memiliki tradisi bahwa mereka mengajarkan doktrin-dotrin mereka secara lisan. Dalam ritual yang disebut dengan symbolia atau acusmata yang artinya sesuatu yang didengar, Pythagoras memberikan petuah-petuahnya di mana apa yang diucapkannya langsung bersumber dari keilahian. ${ }^{65}$ Dari petuah-petuah yang keluar dari mulut Pythagoras inilah muncul prinsip-prinsip ajaran sekte Pythagorean yang dipatuhi baik oleh Pythagoras sendiri maupun oleh pengikutnya.

${ }^{64}$ Huffman, "Pythagoras".

${ }^{65}$ Ibid. 
Satu hal yang perlu dicermati adalah kaum Pythagorean sangat serius dalam memandang matematika. Tidak seperti ilmuwan atau matematikawan zaman sekarang yang memandang matematika sebagai hal yang sekuler atau profan, Pythagorean melihat aktivitas matematika sebagai aktivitas ketuhanan. Kegiatan dalam matematika, baik mengukur, menghitung, membuktikan teorema, dan yang lainnya merupakan sebuah ritual. Kajian terhadap bentuk-bentuk geometris membangkitkan jiwa untuk membaca bentuk-bentuk abadi, karena bentuk-bentuk ini merupakan karya geometris Tuhan yang digunakan untuk memahami kosmos. ${ }^{66}$ Dengan aktivitas tersebut mereka merasa tengah berurusan dengan Yang Sakral. Oleh karenanya, aktivitas matematika bagi mereka adalah salah satu bentuk ritual bagi mereka untuk menyentuh realitas yang lebih tinggi, atau dengan kata lain menyatu dengan Yang Sakral. Dengan aktivitas tersebut, anggota sekte merasa memiliki kesatuan rasa dan inilah yang mengikat mereka ke dalam suatu komunitas yang tunggal.

\section{Penutup}

Sekte Pythagorean merupakan suatu kelompok religius karena memiliki bentuk-bentuk keagamaan dasar. Bentuk-bentuk berikut berupa angka sebagai sang sakral, adanya totem berupa bentuk geomtris tertentu dan perbandingan-perbandingan numerik, adanya tabu yang menjaga kesakralan pemahaman terhadap divinitas angka dan aktivitas matematika serta petuah-petuah dari Pythagoras sebagai ritual khusus mereka. Bentuk keagamaan tersebut merupakan suatu sistem religius dalam sekte Pythagorean. Pythagorean memandang angka sebagai Yang Sakral. Angka dan matematika bukanlah hal profan, namun merupakan The Devine Providence (Sang Maha Penjaga) atas alam semesta. Dengan kepercayaan inilah mereka membangun sistem religiositas mereka. Dengan yang sakral sebagai entitas tertinggi, mereka membentuk pemahaman akan realitas.

Sekte Pythagorean memiliki kepercayaan akan totem yang merupakan salah satu unsur penting dalam keagamaan yang memiliki fungsi sebagai lambang, pembeda sang sakral dan profan, dan pusat

${ }^{66}$ Heninger, Touch of Sweet, 144. 
ritual. Angka, perbandingan emas dan bentuk-bentuk geometris khususnya pentagram merupakan totem bagi sekte Pythagorean karena mereka merupakan lambang dari sekte, perwujudan atas yang sakral, dan menyediakan konsepsi atas kosmos.

Ritual-ritual yang merupakan inti dari bentuk keagaman banyak ditemui dalam tradisi Pythagorean. Ritual positif berfungsi mendekatkan yang sakral dan mengikat kesatuan komunitas seperti berbagai tradisi asketik sekte Pythagorean, dan ritual negatif atau tabu bertujuan untuk melarang perbuatan tertentu dan menghukum pelanggar yang mencederai pemahaman religiositas mereka. Inti utama ritual adalah untuk menumbuhkan rasa keagamaan di mana perasaan yang muncul tersebut adalah bagian dari Yang Sakral.

Dari berbagai analisa di atas terlihat bahwa berbagai pemahaman matematika, terkait angka, geometri, dan perbandingan merupakan suatu bentuk religiositas dalam pandangan sekte Pythagorean. Aktivitas matematika yang dalam masa sekarang dipandang sebagai yang profan, merupakan suatu aktivitas religius dalam sekte Pythagorean. Dalam hal ini, matematika dalam sekte Pythagorean adalah bagian dari elemen keagamaan.

\section{Daftar Pustaka}

Davies, Paul. Membaca Pikiran Tuban: Dasar-dasar Ilmiah dalam Dunia yang Rasional, terj. Hamzah. Yogyakarta: Pustaka Pelajar, 2002.

Durkheim, Emile. The Elementary Forms of The Religious Life. Yogyakarta: Diva Press, 2011

Gie, The Liang. Filsafat Matematik. Yogyakarta: Penerbit Supersukses, 1981.

Heninger, S. K. Touch of Sweet Harmony: Pythagorean Cosmology and Renaissance Poetics. California: Angelico Press, 2013.

Hidayah, Sita. "The Politics of Religion The Invention of "Agama" In Indonesia". Kawistara 2 (2012): 9. 
Huffman, Carl. "Pythagoras" dalam http://plato.stanford.edu/23 Februari 2005/ diakses 20 September 2014.

Kuhn, K. Charles. Pythagoras and The Pythagoreans: A Brief History. Indianapolis: Hackett Publishing, 2001.

Pals, Daniel L. Seven Theories of Religion. Yogyakarta: Diva press, 2011.

Seife, Charles. Biografi Angka Nol. Yogyakarta: E-Nusantara, 2000.

Suriasumantri, Jujun S. Filsafat Ilmu: Suatu Pengantar Populer. Jakarta: Pustaka Sinar Harapan, 2009.

Thesleff, Holger. "Pythagoreanism" dalam http://www.britannica.com. 21 Februari 2013/diakses 20 September 2014.

Wikipedia. "Golden Ratio" dalam http://en.wikipedia.org. 1 January 2010/ diakses 21 November 2014. 